\section{Haukeland universitetssjukehus}

Helse Bergen, Haukeland universitetssjukehus, har om lag 11800 tilsette som kvar dag har som mål å gje best mogleg behandling og pleie til pasientane.

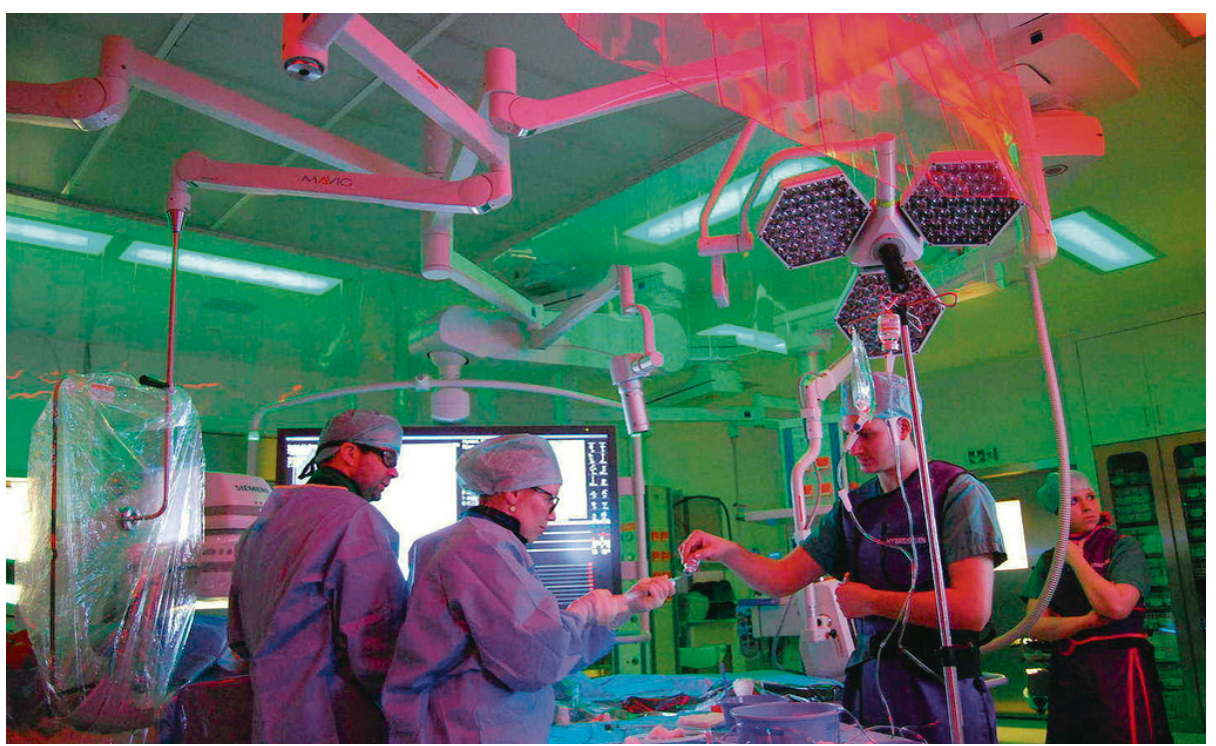

Radiologisk avdeling, Haukeland universitetssjukehus. Foto: Kari Fosse/Beathe Tollefsen

Dei tilsette er den viktigaste ressursen. Sjukehuset arbeider for å knytte til seg dei beste fagfolka og vil legge til rette for at alle tilsette skal trivast og yte sitt beste. Visjonen for Helse Bergen er å fremme helse og livskvalitet i vest. Dette skal dei gjere gjennom å vise respekt i møte med pasienten, sørge for kvalitet i prosess og resultat og skape tryggleik for tilgjengelegheit og omsorg.

Slik skal sjukehuset oppnå dei overordna måla som er

- trygge og nære helsetenester

- heilskapleg behandling og effektiv ressursbruk

- ein framtidsretta kompetanseorganisasjon

Kvart år behandlar sjukehuset nesten 600000 pasientar og utdannar eit par tusen helsearbeidarar. Forsking er ei viktig oppgåve, og Haukeland er Noregs nest største medisinske forskingsmiljø.

Helse Bergen er ein arbeidsstad der ein får gode moglegheiter for både fagleg og personleg utvikling. Det er eit stort mangfald av yrker og jobbar som skal til for å oppfylle visjonen om å fremme helse og livskvalitet til befolkninga i vest.

\section{Idrettslag}

Haukeland sykehus idrettslag (HSI) har i dag om lag 1500 medlemmer, fordelt på 27 grupper. Eit felles mål for Helse Bergen og idrettslaget er å støtte førebyggjande og helsefremjande arbeid ved å tilby tilsette trening og aktivitet. Tilbodet er mangfaldig, med blant anna fotball, handball, aerobic, orientering, innebandy, volleyball, turgruppe, friidrett, golf og styrketrening.

\section{Barnehagane}

Helse Bergen har fem barnehagar som er spesielt tilrettelagt for tilsette som jobbar i føretaket. Alle som er tilsett i Helse Bergen, eller som skal starte i ny stilling i føretaket, kan søkje om barnehageplass for barna sine.

\section{www.legejobber.no}

28.05 .

FRIST FOR INNSENDELSE AV ANNONSER TIL NR. 11/2014

\section{Om Legejobber.no}

Legejobber.no er Tidsskriftets stillingsportal for leger og for stillingsannonsører.

Som annonsør kan du nå bestille annonsen døgnet rundt via Legejobber.no. Du registrerer nettannonsen og papirannonsen samtidig.

Som jobbsøker kan du på Legejobber.no enkelt søke etter ledige jobber etter spesialitet, geografisk område eller i fritekst.

\section{Ønsker du å motta varsel om ledige stillinger innenfor et bestemt område? \\ På Legejobber.no kan du abonnere på ledige stillinger.}

\section{Priser på stillingsannonser 2014}

* Gjelder for kombinasjon papir/nett.

\section{Format}

1/1-side

Pris svart-hvitt

Størrelse

Pris 4 farger

$185 \times 245$

31600

34700

$1 / 2$ s. liggende

$185 \times 112$

Pris svart-hvitt

17000

Pris 4 farger

20000

1/2 s. stående

$90 \times 245$

Pris svart-hvitt

17000

Pris 4 farger

20000

1/4 side

Pris svart-hvitt

$90 \times 112$

Pris 4 farger

9000

11000

1/8 side

$90 \times 45$

Pris svar-hvitt

Pris 4 farger 